\title{
The effects of inspecting and constructing part-task- specific visualizations on team and individual learning
}

Citation for published version (APA):

Slof, B., Erkens, G., Kirschner, P. A., \& Helms-Lorenz, M. (2013). The effects of inspecting and constructing part-task-specific visualizations on team and individual learning. Computers \& Education, 60(1), 221-233.

https://doi.org/10.1016/j.compedu.2012.07.019

DOI:

10.1016/j.compedu.2012.07.019

Document status and date:

Published: 01/01/2013

Document Version:

Other version

Please check the document version of this publication:

- A submitted manuscript is the version of the article upon submission and before peer-review. There can be important differences between the submitted version and the official published version of record. People interested in the research are advised to contact the author for the final version of the publication, or visit the DOI to the publisher's website.

- The final author version and the galley proof are versions of the publication after peer review.

- The final published version features the final layout of the paper including the volume, issue and page numbers.

Link to publication

\section{General rights}

Copyright and moral rights for the publications made accessible in the public portal are retained by the authors and/or other copyright owners and it is a condition of accessing publications that users recognise and abide by the legal requirements associated with these rights.

- Users may download and print one copy of any publication from the public portal for the purpose of private study or research.

- You may not further distribute the material or use it for any profit-making activity or commercial gain

- You may freely distribute the URL identifying the publication in the public portal.

If the publication is distributed under the terms of Article 25fa of the Dutch Copyright Act, indicated by the "Taverne" license above, please follow below link for the End User Agreement:

https://www.ou.nl/taverne-agreement

Take down policy

If you believe that this document breaches copyright please contact us at:

pure-support@ou.nl

providing details and we will investigate your claim.

Downloaded from https://research.ou.nl/ on date: 26 Apr. 2023 


\title{
The effects of inspecting and constructing part-task-specific visualizations on team and individual learning
}

\author{
Bert Slof ${ }^{a, *}$, Gijsbert Erkens ${ }^{b}$, Paul A. Kirschner ${ }^{c}$, Michelle Helms-Lorenz ${ }^{a}$ \\ ${ }^{a}$ University of Groningen, P.O. Box 800, 9700 AV Groningen, The Netherlands \\ ${ }^{\mathrm{b}}$ Utrecht University, P.O. Box 80.140, 3508 TC Utrecht, The Netherlands \\ 'Open University of the Netherlands, P.O. Box 2960, 6401 DL Heerlen, The Netherlands
}

\section{A R T I C L E I N F O}

\section{Article history:}

Received 25 April 2012

Received in revised form 8 July 2012

Accepted 13 July 2012

\section{Keywords:}

Complex learning

Computer-supported collaborative learning

Inspecting and constructing visualizations

Instructional support

Problem representations

\begin{abstract}
A B S T R A C T
This study examined whether inspecting and constructing different part-task-specific visualizations differentially affects learning. To this end, a complex business-economics problem was structured into three phase-related part-tasks: (1) determining core concepts, (2) proposing multiple solutions, and (3) coming to a single solution. Each phase was foreseen with a part-task-specific representational tool facilitating visualization of the domain-content (i.e., a conceptual, causal and simulation tool respectively for the subsequent phases). Whereas all teams of learners $(N=17)$ were scripted to carry out the parttasks in the predefined order, teams were instructed to (1) inspect expert visualizations $(n=8)$ or $(2)$ construct their own domain-specific visualizations $(n=9)$. Results indicate that constructing visualizations, in comparison to inspecting them, evokes more meaningful discussion of the domain-content beneficially affecting team complex learning-task performance and individual learning gains (i.e., higher post-test score).
\end{abstract}

() 2012 Elsevier Ltd. All rights reserved.

\section{Introduction}

The interest in complex learning is often regarded as education's response to the rapidly changing demands of society and work. Complex learning is necessary to carry out activities endemic to modern society, such as complex tasks or problems which (1) cannot be described in detail, (2) give no certainty about what the best solution is, and (3) require different perspectives on the problem and the problem-solving strategy for their solution (Jonassen, 2003; Spector, 2008). Learning to flexibly solve complex problems is, thus, an educational priority. To this end, schools incorporate educational approaches such as collaborative and/or individual problem-solving into their curricula (Hmelo-Silver, Duncan, \& Chinn, 2007; Mergendoller, Maxwell, \& Bellisimo, 2006). In problem-based learning approaches, learners are usually confronted with a case containing a problem for which a suitable solution must be found. To accomplish this, learners carry out a number of phase-related activities, namely (1) problem-orientation where the core concepts are determined and related to the problem, (2) problem-solution where multiple solutions to the problem are proposed, and (3) solution-evaluation where the suitability of the different solutions is determined and a definitive solution to the problem is chosen (Bigelow, 2004; Van Merriënboer \& Kirschner, 2007).

When learners carry out such complex learning tasks without proper instructional support, they often experience difficulties leading to inefficient and ineffective learning (Kirschner, Sweller, \& Clark, 2006; Reiser, 2004). In contrast to expert problem-solvers, learners (i.e., nonexperts) experience considerable difficulties in solving complex problems. Non-experts rely primarily on superficial features such as using objects referred to in the problem instead of the underlying principles of the knowledge domain (Corbalan, Kester, \& Van Merriënboer, 2009), and employ weak problem-solving strategies such as working with a means-ends strategy toward a solution (Dufresne, Gerace, Thibodeau-Hardiman, \& Mestre, 1992). They lack a well-developed understanding of the knowledge domain and consequently have problems creating and combining meaningful problem representations. This hinders them in effectively and efficiently coping with their problem-solving task because the ease with which a problem can be solved often depends on the quality of the available problem

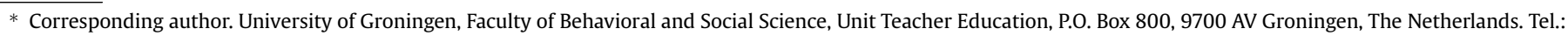
+31 (0)50 3636611.

E-mail address: B.Slof@rug.nl (B. Slof).
} 